\title{
地震時人的被害予測に向けた人体の地震応答解析モデルの構築 \\ 振動台搭乗実験に基づく台車型倒立振子モデルによるシミュレーション解析 \\ CONSTRUCTION OF SEISMIC RESPONSE ANALYTICAL MODEL OF HUMAN BODY FOR PREDICTING HUMAN DAMAGE DURING EARTHQUAKE
}

Simulation analysis based on shaking table test and cart-type inverted pendulum model

\author{
肥田剛 典*1, 大野敦史 ${ }^{* 2}$, 糸井達哉*3, 高田毅士*4 \\ Takenori HIDA, Atsushi OHNO, Tatsuya ITOI \\ and Tsuyoshi TAKADA
}

\begin{abstract}
In this study, the shaking table tests with a human subject were conducted to construct a seismic response analytical model of a human body for evaluating human injury. The mechanisms of postural control of the human subject were investigated. Next, the seismic response analytical model of a human was constructed based on the inverted pendulum model with feedback controller. The frequency response function of the human subject and that of the analytical model was compared to set the appropriate feedback gain. Finally, the validity of the model was verified by the simulation analysis with other input motion.
\end{abstract}

Keywords : Human body, Shaking table test, Postural control, Inverted pendulum, Feedback control 人体, 振動台実験, 姿勢制御, 倒立振子, フィードバック制御

\section{1. はじめに}

これまで発生した被害地震時において、多くの人的被害が報告さ れている例えば1)-6)。地震時のけがの要因としては、主に割れたガラス や食器による切傷、家具の転倒による打撲等が多いが、人間の転倒 や物一の衝突による打撲や骨折等の報告例も少なくない例衤弪1), 2), 6)。 地震が発生した際、化学プラントや原子力発電所等の重要構造物に おいては、運転員や作業員の人命確保が最優先であることは言うま でもないが、地震により事故が生じた場合、運転員は有害物質漏洩 防止等のための事故後対応を行うことが要求される。しかし、地震 の摇れによって作業員が負傷した場合、事後対応が困難となる可能 性がある。また、今後の発生が危惧されている南海トラフ地震等の 巨大地震時における室内人的被害の予測を行う上でも、地震時にお ける人間の挙動を把握することが重要である。

地震時室内被害の予測を目的とした既往の研究として、家具の転 倒に関する研究がある例えば7)-9)。正月ら 8)および荻野ら 9)は、地震時 における家具の転倒や移動を計算機上でシミュレートする手法を構 築している。ただし、家具の転倒が人間の負傷に及ぼす影響を検討 するためには、家具の転倒可能性の評価だけでは不十分である。こ れに対し、宮野ら 10 ) は、地震時における人体被災度計測手法を開発 するため、大腿部や胸部圧迫実験用のダミー人形を開発した。高橋
ら ${ }^{11}$ は、地震時における家具の転倒が人体に及ぼす影響について、 ダミー人形を用いた実験により検討している。ただし、これらは人 体の地震時応答については言及していない。甲斐ら ${ }^{12}$ ) は、振動台に ダミー人形を載せて加振実験を行い、その振動特性について検討し ている。これに対し、筆者らは、着座式の可搬型地震動シミュレー ター13)を用いて、人間とダミー人形の振動特性を比較し、固有振動 数や減衰定数等の振動特性が人間とダミー人形で大きく異なること を示した ${ }^{14)}$

Takahashi et al. $\left.{ }^{15}\right)$ は、人間を振動台に乗せた振動台搭乗実験を 行っている。しかし、この実験で用いられた入力波は正弦波であり、 被験者の挙動は実地震時とは異なる可能性がある。また、この研究 は摇れの最中における行動難度や不安度を調べる目的で行われてお り、地震時の負傷等の物理的な人的被害に言及したものではない。 また、坂本ら 16) は振動台搭乗実験を行い、人間の地震時の体感につ いて検討している。入力波には 2011 年東北地方太平洋沖地震（以 降、3.11 本震) 時に超高層集合住宅内で観測された強震記録が用い られ、行動難度や不安度の評価のみならず、人体の頭部の応答につ いても検討している。しかし、この研究の目的は、行動難度を人体 の応答に基づいて評価することであり、負傷等の人的被害評価につ いては言及されていない。

\footnotetext{
*1 東京大学大学院工学系研究科建築学専攻 助教 $\cdot$ 博士 (工学)

*2 東京大学大学院工学系研究科建築学専攻 大学院生

*3 東京大学大学院工学系研究科レジリエンス工学研究センター 准教授・博士 (工学)

*4 東京大学大学院工学系研究科建築学専攻 教授・工博
}

Assist. Prof.. Dept. of Architecture, Graduate School of Engineering. The University of Tokyo, Dr.Eng:

Grad. Student, Dept. of Architecture, Graduate School of Engineering, The University of Tokyo

Assoc. Prof., Resilience Engineering Research Center, Graduate School of Engineering, The University of Tokyo, Dr.Eng.

Prof., Dept. of Architecture, Graduate School of Engineering, The University of Tokyo, Dr.Eng. 
地震の摇れによる人間の転倒や家具等との衝突による負傷の評価 を行うためには、人体の地震応答を評価する必要がある。しかし、 振動台搭乗実験においては被験者の安全を最優先に考えるべきであ るため、実験により被験者の負傷に関するデータを得ることは不可 能である。そこで、人間の地震応答解析モデルを構築することが出 来れば、計算機上で人体の負傷を予測することが出来る。

これまで、床面の振動等の外乱に対する人体の応答を再現するモ デルの構築に関する様々な研究が行われてきた。床面の回転に対す る人体の立位姿勢制御 17)や、床面の水平移動に対する姿勢制御 18)に ついて、フィードバック制御器を有する倒立振子によりモデル化し た研究例がある。ただしこれらの研究の目的は、人体の姿勢制御メ カニズムを解明することであり、地震時における人間の転倒や負傷 を予測することではない。

建築分野における人体の地震応答解析モデルの構築に関する先駆 的な研究として、山本 ${ }^{19)}$, 20)の研究がある。この研究では、振動台に 人間を乗せて加振を行い、立位および座位時の人体の振動特性につ いて検討し、人体の簡易応答モデルを構築している。ただし、この 研究の目的は、建築構造物の振動制御に人間の振動特性の考え方を 取り入れることや、床振動に対する人間の官能を評価することであ り、人体の地震時応答をシミュレートすることではない。この振動 台実験では最大振幅 $0.8 \mathrm{~m} / \mathrm{s}^{2}$ の正弦波 Sweep 加振が行われており、 その応答特性は複雑かつ大振幅の強震時の挙動と異なる可能性があ る。また、この実験で計測されたのは床反力のみであり、被験者の 身体各部位の応答特性については検討されておらず、身体の実挙動 を用いたモデルの妥当性の検証はなされていない。さらに、この実 験では被験者は足を踏み出さず、静止立位時の人体の応答を検討し ているにとどまる。

強震時に人間がよろめいた場合、姿勢を制御するために足を踏み 出す。その際にバランスを崩して転倒する可能性もあり、また周囲 の壁や家具等の障害物に衝突する危険性もある。衝突する際の身体 や頭部の速度を知ることが出来れば、頭部傷害基準值(Head Injury

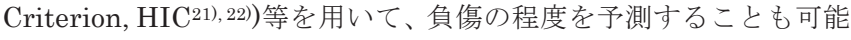
となろう。地震時の負傷等の人的被害の予測を行うためには、人間 の身体や頭部の変位、速度、足の踏み出しを予測できる人体の地震 応答解析モデルを構築することが極めて重要である。しかし、これ まで述べてきたように、そのようなモデルを構築した研究例は無い。

以上の背景をふまえ、筆者らはこれまで、実地震時に観測された 強震記録を用いた振動台搭乗実験を実施し、人体の地震応答解析モ デルの構築に向けた検討 23)-25)を行ってきた。それに加え、本論文で は同様の振動台搭乗実験を行い、摇れの最中における被験者の身体 重心と床反力中心の挙動の関係を分析し、姿勢制御メカニズムにつ いて考察する。さらに、振動台搭乗実験データに基づき、床反力中 心位置や人体の重心の変位、重心や頭部の速度を再現可能な台車型 倒立振子に基づく地震応答解析モデルを構築する。

\section{2. 振動台搭乗実験}

\section{1 実験概要}

振動台搭乗実験の状況を Photo 1 に示す。実験は、東京大学柏キ ヤンパスの千葉実験所において、2017 年 12 月 20 日および 21 日に 実施した。振動台のサイズは $5 \mathrm{~m} \times 5 \mathrm{~m}$ で、水平 2 軸加振が可能であ る。振動台上の外周に鋼製単管パイプを用いて手寸りを構築し、手 すりの上部に 6 台のビデオカメラ（画像サイズ: 1920 px×1080 px, フレームレート: $59.94 \mathrm{fps}$ )を設置して加振中の被験者の挙動を撮影 する。ビデオカメラは振動台上面から 2.6m (4 台)と 2.0m (2 台)の高 さに設置した。振動台には加速度計（水平 2 方向）を設置した。

被験者の詳細を Fig. 1 に示す。被験者は 24 歳男性である。被験者 にはヘルメットを被せ、肘、掌、腰および膝にプロテクタを装着さ せた。また、被験者にはゴム底のスニーカーを履かせた。モーショ ンキャプチャにより身体各部位の挙動を記録するため、ヘルメット 上部、両肩、両肘、両手首、腰の左右、両膝、両足の踝および足の 甲側部に球形発泡スチロール製のマーカー（直径 $35 \mathrm{~mm}$ ）を貼付し た。マーカーの色はピンク色とし、プロテクタや靴（黒）、衣服（濃

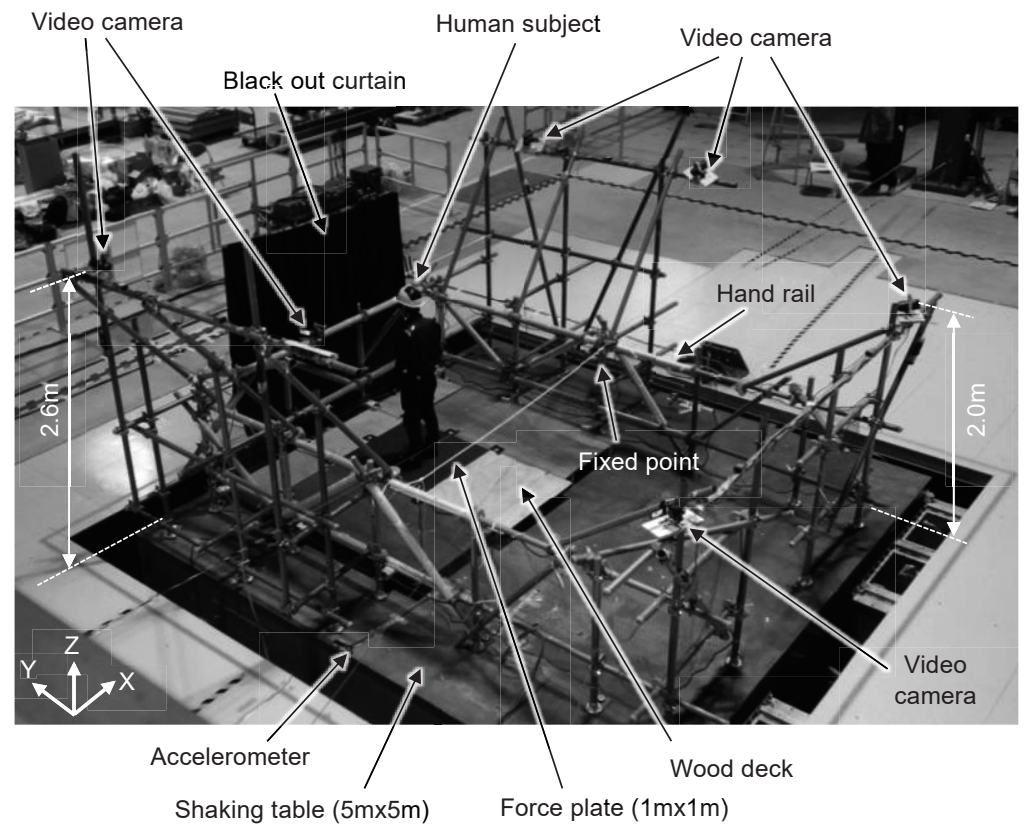

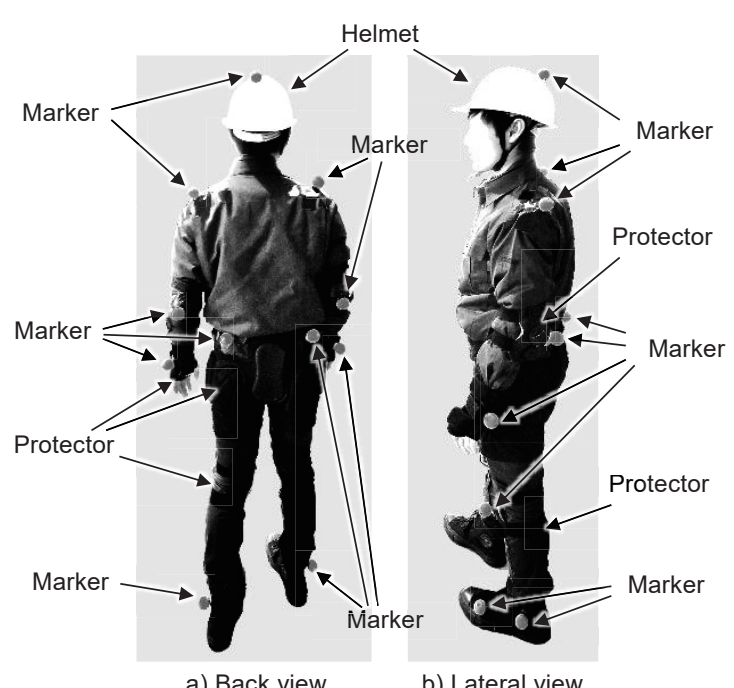

a) Back view

b) Lateral view

Fig. 1 Human subject

Photo 1 Shaking table test 
紺）の色と区別できるよう配慮した。さらに、被験者の前面に暗幕 を設置し、被験者の視界を遮ることとした。被験者には可能な限り 手寸りにつかまらないよう指示したが、足の踏み出しについては制 限していない。なお、実験に先駆け、被験者には実験の目的や留意 事項を説明し、承諾を得ている。

本実験では振動台上にビデオカメラを設置しているため、モーシ ヨンキャプチャによって求められるマーカーの挙動は、振動台に対 する相対変位となる。振動台の挙動も同時に記録するため、振動台 の外部に固定された柱等から振動台の上空を横切るようにワイヤー を張り、そのワイヤー上に、振動台上のビデオカメラに映る位置に マーカーを貼付した。このマーカーは空中に固定された不動点とな る。振動台に対する不動点の相対変位をモーションキャプチャによ って求め、その符号を逆転させることで、振動台の絶対変位を求め ることができる。

被験者の床反力を計測するため、振動台上にフォースプレートを 設置した。フォースプレートとロードセルの配置および支持基底面 (Base of Support, BoS)、人体の質量中心 (Center of Mass, CoM)、重心 (Center of Gravity, CoG)および床反力中心 (Center of Pressure, CoP) の位置関係を Fig. 2 a), b) に示寸。CoG は CoM を床面に投影した点 であり、 CoP は足裏に作用する床反力の合力ベクトルの床面との交 点である。 BoS は両足の接地面を内包する凸領域である。フォース プレートは、剛性を高くし、かつ重量を最小限にするため、アルミ ニウム製のハニカムパネル（サイズ: $1 \mathrm{~m} \times 1 \mathrm{~m}$, 質量: 約 $28 \mathrm{~kg}$ ) を用 いた。被験者のフォースプレートからの落下を防ぐため、フォース プレートと同じ高さの木製のデッキをフォースプレートの周囲に配 置した。

パネルの 4 隅をロードセルで鉛直支持した。ロードセル周辺の断 面詳細図を Fig. 2 c) に示す。 4 台のロードセルが均等に八ニカムパ ネルを支持できるよう、ロードセルをアジャスターボルトで支持す ることで、高さの調整が可能な仕様とした。ローラーでハニカムパ ネルの水平方向の移動を拘束した。八ニカムパネル上面にはタイル カーペットを敷設した。

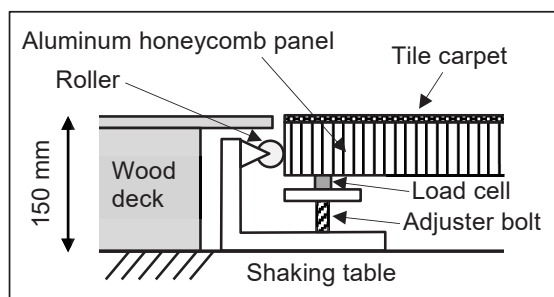

c) Detailed view around load cell (Section view)

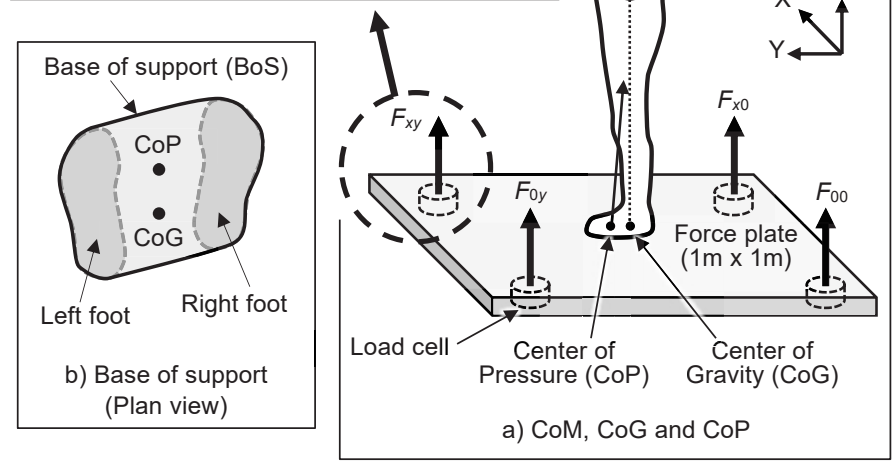

Fig. 2 Force plate
各ロードセルの荷重值から、X 方向（被験者の左右方向）の CoP 変位 $x_{\mathrm{COP}}$ および $\mathrm{Y}$ 方向（被験者の前後方向）の $\mathrm{CoP}$ 变位 $y_{\mathrm{CoP}}$ を次式 により求める ${ }^{26)}$ 。

$$
\begin{aligned}
& x_{\mathrm{CoP}}=\frac{L_{x}}{2}\left\{1+\frac{F_{x 0}+F_{x y}-\left(F_{00}+F_{0 y}\right)}{F_{\text {sum }}}\right\} \\
& y_{\mathrm{CoP}}=\frac{L_{y}}{2}\left\{1+\frac{F_{0 y}+F_{x y}-\left(F_{00}+F_{x 0}\right)}{F_{\text {sum }}}\right\}
\end{aligned}
$$

ここに、 $L_{x}$ および $L_{y}$ は X 方向および $\mathrm{Y}$ 方向のロードセル間距離、 $F_{00}, F_{x 0}, F_{0 y}, F_{x y}$ は Fig. 2 a) に示した各位置のロードセルによる荷重 值、 $F_{\text {sum }}$ は 4 つのロードセルの荷重の合計である。なお、ハニカム パネルの水平力を受けるローラーの高さが八ニカムパネル上面の高 さと一致しない場合、CoP 変位に誤差が生じる。しかし、ハニカム パネル上面とローラー支持点の高さの差が極めて小さいため、その 誤差を無視することとした。フォースプレートに錘を載せて加振を 行い、錘の加速度を計測し、それから求めた $\mathrm{CoP}$ の変位とフォース プレートのロードセルから求めた $\mathrm{CoP}$ 変位が良好に一致したこと を確認している。

入力波の一覧を Table 1 に示す。入力波は 7 種類とし、いずれも原 子力発電所内で観測された強震記録である。Case 1 3 は 2007 年新 潟県中越沖地震本震 (以降、中越沖地震) 時に柏崎刈羽原子力発電 所の 7 号機原子炬建屋の 3 階で観測された波形 27)で、振幅をそれぞ れ 0.5 倍, 0.7 倍, 1.0 倍したものである。Case 4〜 6 は 3.11 本震時に 福島第一原子力発電所の 6 号機原子炉建屋の 6 階で観測された波形 28)で、振幅をそれぞれ 0.5 倍, 0.85 倍, 1.0 倍したものである。Case 7 は 3.11 本震時に同原子力発電所の免震重要棟の 1 階において観測さ れた波形 ${ }^{28)}$ である。加振前に入力波形の名称は被験者に知らせず、 加振の順番はランダムとした。

Case 3, Case 6 および Case 7 において振動台上で観測された加速 度時刻歴波形を Fig. 3 に示す。Case 3 の継続時間は Case 6,7 の 1/4 程 度である。Case 6 の最大加速度が最も大きく、次いで Case 3 の最大 加速度が大きい。Case 7 の最大加速度は、Case 6 の 1/2 程度である。

Case 3, 6 および 7 の振動台加速度の加速度応答スペクトルを Fig. 4 に示す。Case 3 および Case 6 はいずれも 1 秒以下の周期帯の振幅 が大きい。一方、Case 7 は Case 3, 6 に比べ全体的に振幅は小さく、 $\mathrm{X}$ 方向は 0.6 秒付近で卓越し、Y 方向は 1.3 秒付近で卓越している。

\section{2 実験結果}

6 台のビデオカメラによって加振中の被験者の挙動を撮影した。 加振中の手寸りの振動により動画にブレが生じたため、記録した動 画のブレを Open $\mathrm{CV}^{29}$ を用いて除去した。その後、3D モーションキ ヤプチャ $\left(\right.$ DippMotion- $\left.-\mathrm{V}^{30}\right)$ により被験者の各部位のマーカーの変 位波形を得た。このデータから、被験者の重心 $(\mathrm{CoG})$ の変位を求める。

まず、身体部分を体幹+頭(Trunk + head), 上腕(Upper arm), 前 腕+手 $($ Forearm + hand $)$, 大腿 $($ Thigh $)$ および足+下腿 $($ Foot + leg $)$ の 5 つの部分（左右で総計 9 つの部分）に分ける。CoG 変位を求める ため、各身体部分の重心の座標を次式により求める ${ }^{31}$ 。

$$
x_{c g}^{(i)}(t)=x_{p}^{(i)}(t)+R_{p}^{(i)}\left(x_{d}^{(i)}(t)-x_{p}^{(i)}(t)\right)
$$


Table 1 Input motion ${ }^{27), 28)}$

\begin{tabular}{|c|c|c|c|}
\hline Name & Earthquake name & Observation site & Amp. factor \\
\hline Case 1 & \multirow{3}{*}{ The Niigataken Chuetsu-oki Earthquake in 2007} & \multirow{3}{*}{ Kashiwazaki-Kariwa Nuclear Power Plant, 3rd floor of Unit 7 reactor building } & 0.50 \\
\hline Case 2 & & & 0.70 \\
\hline Case 3 & & & 1.00 \\
\hline Case 4 & \multirow{4}{*}{ The 2011 off the Pacific coast of Tohoku Earthquake } & \multirow{3}{*}{ Fukushima Daiichi Nuclear Power Plant, 6th floor of Unit 6 reactor building } & 0.50 \\
\hline Case 5 & & & 0.85 \\
\hline Case 6 & & & 1.00 \\
\hline Case 7 & & Fukushima Daiichi Nuclear Power Plant, seismically isolation building & 1.00 \\
\hline
\end{tabular}
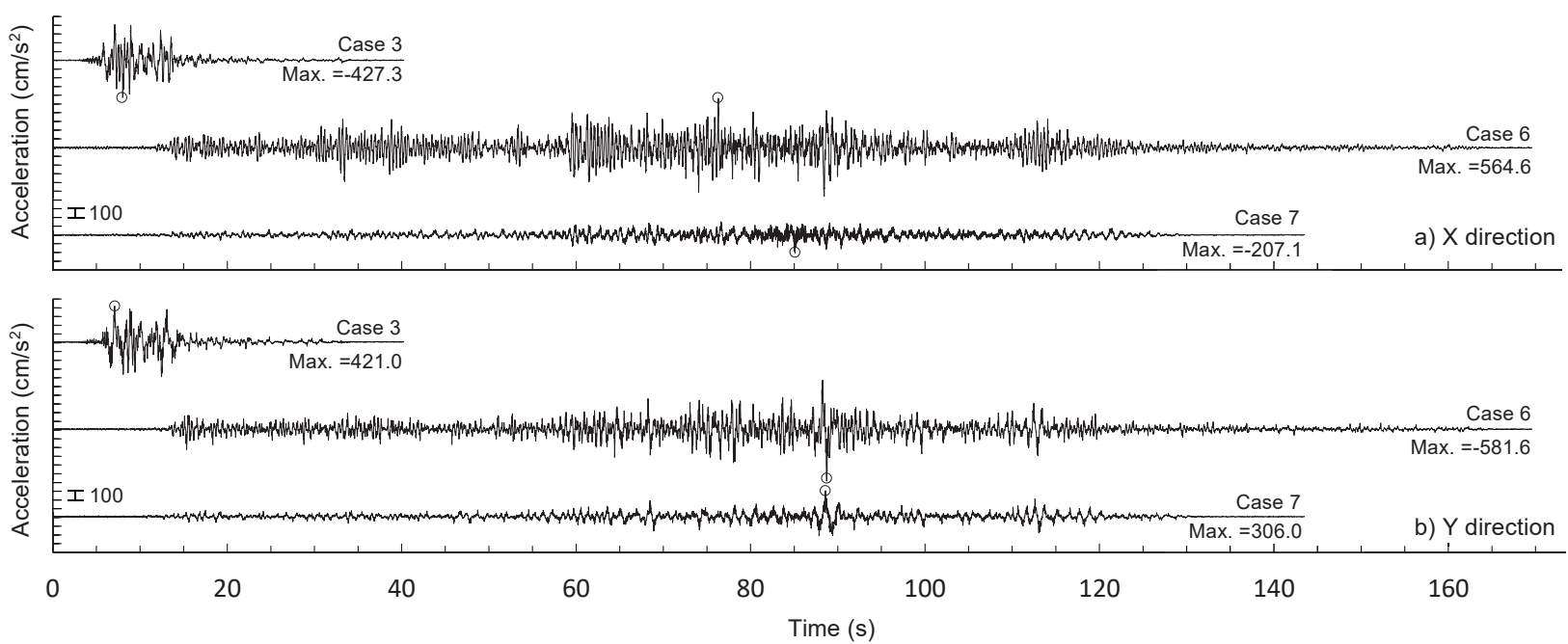

Fig. 3 Acceleration time history ${ }^{27), 28)}$
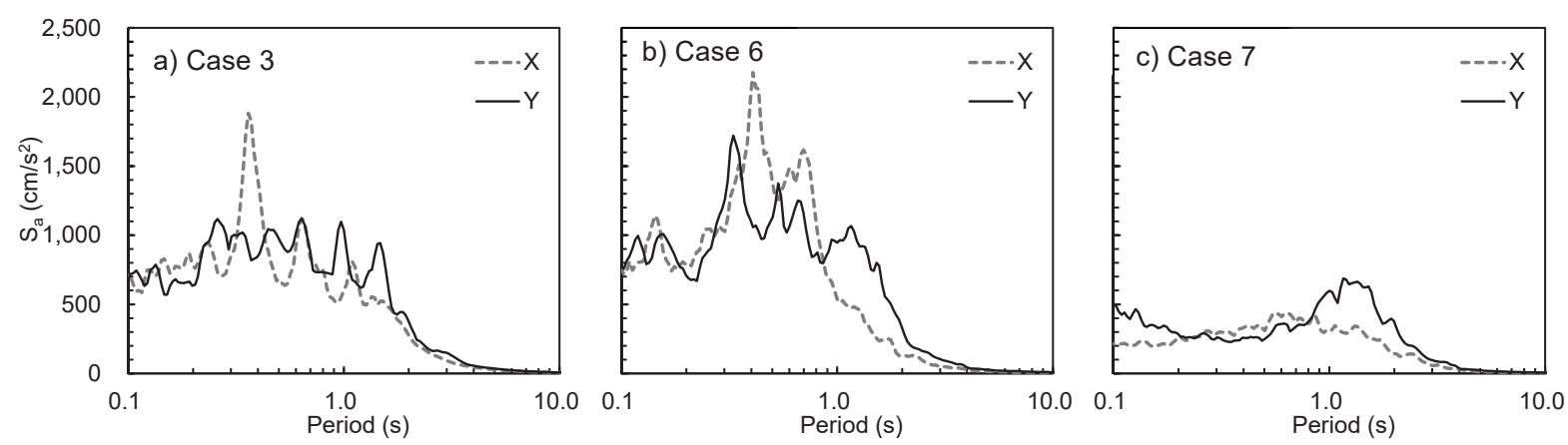

Fig. 4 Acceleration response spectrum $(h=5 \%)^{27), 28)}$

$$
y_{c g}^{(i)}(t)=y_{p}^{(i)}(t)+R_{p}^{(i)}\left(y_{d}^{(i)}(t)-y_{p}^{(i)}(t)\right)
$$

ここに、 $x_{c g}^{(i)}(t)$ および $y_{c g}^{(i)}(t)$ は、時刻 $t$ における身体部分 $i$ の $x$ 方向 および $y$ 方向の重心座標である。また、 $x_{p}^{(i)}(t)$ おうび $y_{p}^{(i)}(t)$ は身体部 分 $i$ の近位端(proximal tip)の $x$ および $y$ 座標で、 $x_{d}^{(i)}(t)$ および $y_{d}^{(i)}(t)$ は身体部分 $i$ の遠位端(distal tip)の $x$ および $y$ 座標である。 $R_{p}^{(i)}$ は、近 位端からの重心位置の距離の身体部分長に対する比である。なお、 近位端は各身体部分における上方に近い端点を意味し、遠位端は遠 い端点を意味する。

続いて、次式により全身の重心位置の $x, y$ 座標 $x_{\mathrm{COG}}$ および $y_{\mathrm{CoG}}$ を 求める ${ }^{31)}$

$$
\begin{aligned}
& x_{\mathrm{CoG}}(t)=\sum_{i=1}^{n} P_{i} x_{c g}^{(i)}(t) \\
& y_{\mathrm{CoG}}(t)=\sum_{i=1}^{n} P_{i} y_{c g}^{(i)}(t)
\end{aligned}
$$

ここに、 $P_{i}$ は身体部分 $i$ の質量比、 $n$ は身体部分の総数である。本研
究では、Table 2 に示した Clauser et al. ${ }^{32)}$, 33)による身体部分の重 心距離比および質量比を用いた。

これ以降、本研究ではY 方向（被験者から見て前後方向）におけ る被験者の挙動のみに着目して検討を進める。被験者の $\mathrm{Y}$ 方向にお ける頭部、肩、腰、両足踝、CoG, CoP および BoS の振動台に対す る相対変位、振動台変位および振動台加速度の時刻歴波形を Fig. 5 に示す。同図の変位波形は、正側が被験者から見て前方、負側が被 験者から見て後方となる。なお、同図 e）には振動台に設置した加 速度計により計測した振動台加速度と、加振中にビデオカメラで撮 影した不動点の変位を 3D モーションキャプチャにより評価し、こ れを時間で 2 階微分して求めた振動台加速度を併記している。モー ションキャプチャにより求めた加速度に対しては、ハイカットフィ ルタにより $8 \mathrm{~Hz}$ 以上の周波数成分を除去した。加速度計により観 測された波形とモーションキャプチャにより求めた波形は良好に一 致しており、モーションキャプチャによる計測が妥当であることが 分かる。 
Table 2 Inertial properties of human body ${ }^{32), 33)}$

\begin{tabular}{ccccc}
\hline \multirow{2}{*}{$\begin{array}{c}\text { Segment } \\
\text { Trunk and head }\end{array}$} & $\begin{array}{c}\text { Endpoints } \\
\text { (proximal to distal) }\end{array}$ & $\begin{array}{c}\text { Segment } \\
\text { Weight/Total Body } \\
\text { Weight }\end{array}$ & \multicolumn{2}{c}{ Center of Mass/Segment Length } \\
\cline { 3 - 5 } Upper arm & Acromion to radiale & 0.5801 & 0.5921 & 0.4079 \\
\hline Forearm and hand & Radiale to stylion & 0.0263 & 0.5130 & 0.4870 \\
\hline Thigh & Trochanter to tibiale & 0.0227 & 0.6258 & 0.3742 \\
\hline Leg and foot & Tibiale to floor & 0.1027 & 0.3719 & 0.6281 \\
\hline
\end{tabular}

外乱を受ける際の立位姿勢制御において、人間は Fig. 6 に示寸 3 つの方略により立位姿勢を保持しようとすることが知られている 34)，35)。1つは足関節方略(Ankle strategy 36 ), 37) )であり、踝を中心之 した回転運動により姿勢を保持する。もう一つは股関節方略 (Hip strategy ${ }^{36}$, 38))であり、股関節の屈曲によって姿勢制御を行う。これ らの方略でも姿勢制御が困難になった場合、ステップ方略 (Stepping strategy 39 ) により姿勢制御を行う。これをふまえて、本 実験における被験者の挙動について分析する。

Fig. 5 において、6 秒から 7 秒にかけて、振動台が前方に変位し、 振動台の加速度振幅が大きくなる。この時点で被験者は足を踏み出 していないが、頭部・肩・腰がわずかに後方に変位する。その後、 7 秒から 7.8 秒にかけて振動台は後方に変位する。このとき、頭部・ 肩・腰が同位相で前方に変位する。同時に、被験者は左足を前方に 約 $30 \mathrm{~cm}$ 踏夕出し、その直後右足を $10 \mathrm{~cm}$ 程度後方に踏み出して おり、ステップ方略により姿勢制御を行っていることが分かる。7 秒 付近において、CoG は前方に $20 \mathrm{~cm}$ 程度变位し、 $\mathrm{CoP}$ も前方に 10 $\mathrm{cm}$ 程度変位する。被験者が左足を踏み出し、床面に足が着地する （Fig. 5 b ， 穴）と同時に BoS が拡大し、 CoP が急激に前方に変位す る。 $\mathrm{CoP}$ は $30 \mathrm{~cm}$ 程度変位し、 $\mathrm{CoG}$ に対してオーバーシュートす る。このように、 CoG に対して $\mathrm{CoP}$ がオーバーシュートすること で姿勢制御を行う様子は、静止立位姿勢制御時にも観測されている 40)。これ以降の時間帯においても、被験者の BoS、CoG および CoP は同様の挙動を示す。

股関節方略が卓越した場合、腰と肩の変位は逆位相となると考え られるが、Fig. 5 a)に見られる通り、頭部・肩・腰の変位は全時間 帯にわたって同位相となっている。このことから、加振中に被験者 は主に足関節方略またはステップ方略により姿勢制御を行ってい ることが分かる。既往の研究において、被験者に対して出来るだけ ステップしないよう指示がなされた場合、立位姿勢制御において股 関節方略が卓越するが、何も指示がない場合には股関節方略をとる ことは少なく、主にステップ方略により姿勢制御を行うことが指摘 されている ${ }^{41}$ 。本研究における実験結果は、これらの既往の研究結 果と調和的である。

振動台が後方に変位した場合におけるステップ方略時の CoG, $\mathrm{CoP}$ および BoS の位置関係の模式図を Fig. 7 に示す。立位姿勢制 御においては、CoG を BoS 内にとどめることが目的である。加振 により床が後方に変位すると、被験者の身体に慣性力が作用して身 体は前傾し、CoG が前方に変位して BoS を逸脱する（または逸脱
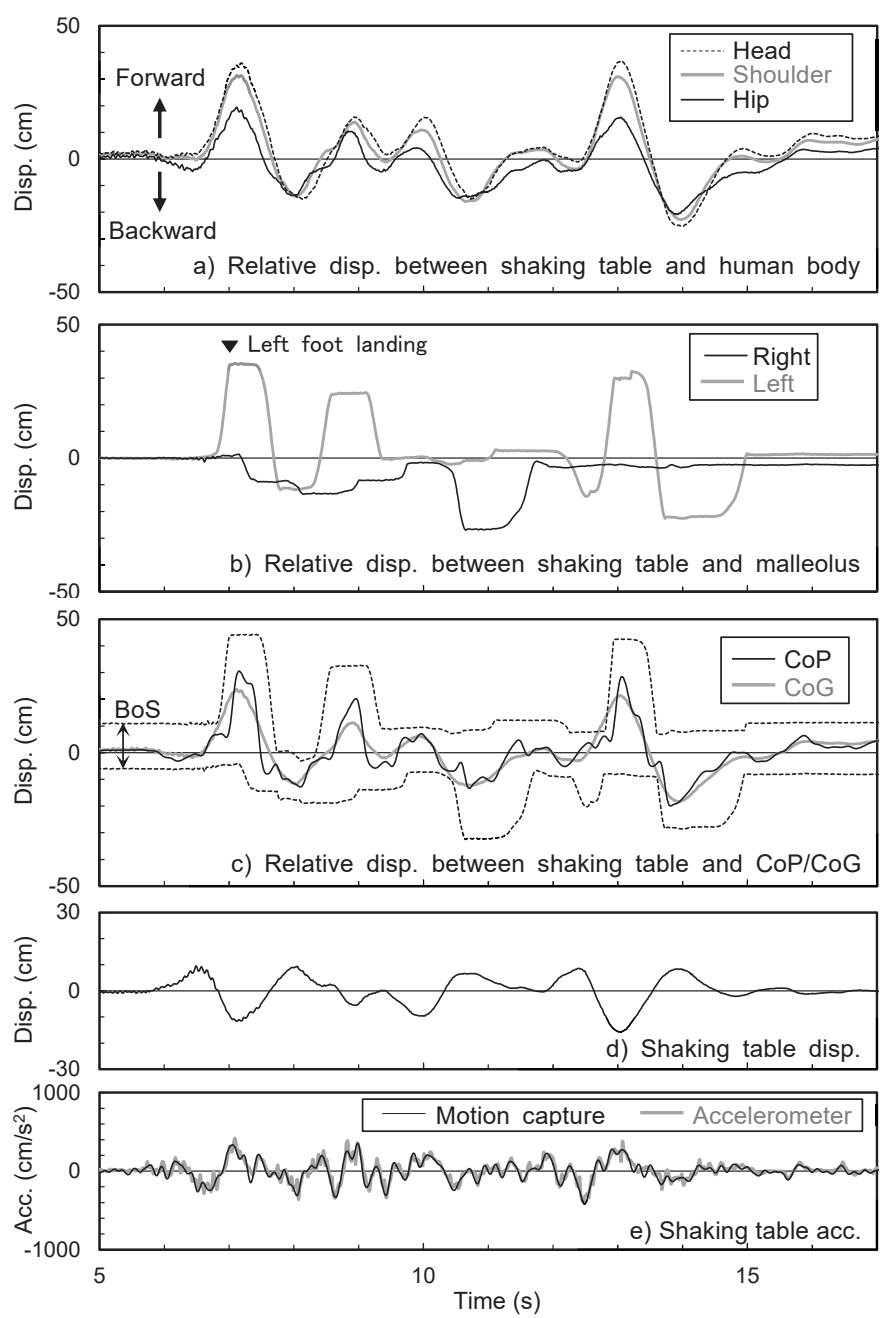

Fig. 5 Time histories of displacement of CoG, CoP, shaking table and acceleration of shaking table (Case $3, Y$ direction)

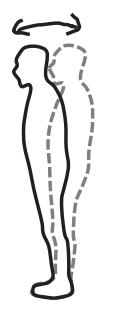

a) Ankle strategy

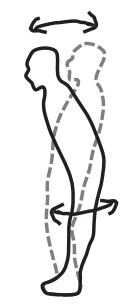

b) Hip strategy

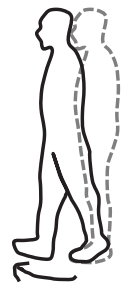

c) Stepping strategy
Fig. 6 Postural control strategies 


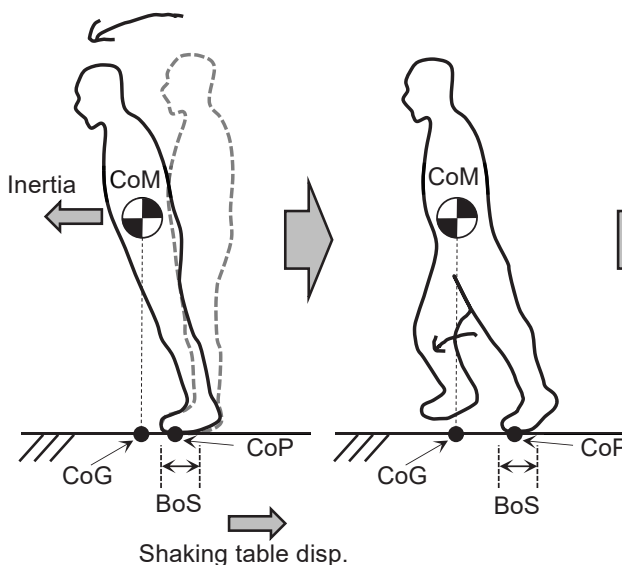

a) CoG (CoM) moving

b) Start stepping

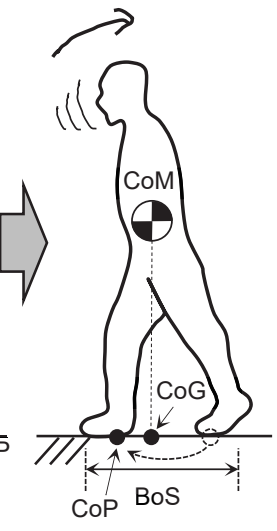

c) Foot landing
Fig. 7 Behavior of CoG, CoP and BoS during stepping strategy

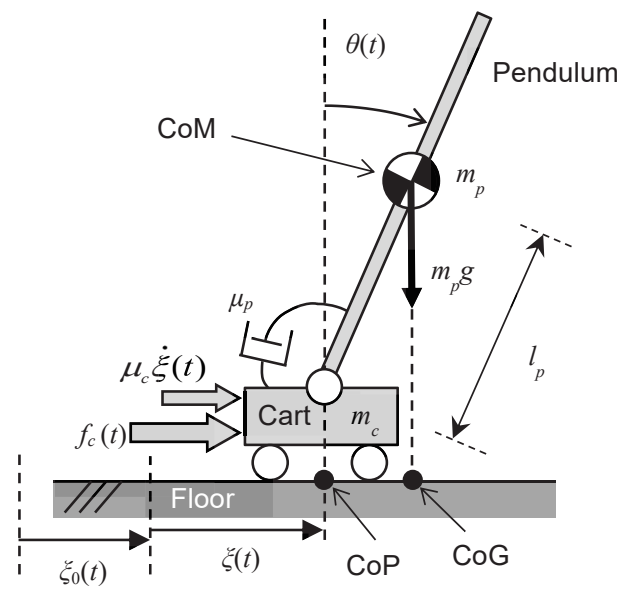

Fig. 8 Seismic response analytical model of human body based on cart-type Inverted pendulum
しそうになる）（Fig. 7 a)。すると、被験者はBoS を拡張すべく片足 を前方に踏み出し始める(Fig. 7 b)。このとき、踏み出した足は宙に 浮いた状態 (遊脚期) であり、BoS は踏み出していないもう片方の 足裏面のみで、 $\mathrm{CoP}$ はその $\mathrm{BoS}$ 内にとどまる。続いて、踏夕出した 方の足が着地すると、BoS が急激に拡大寸る(Fig. 7 c)。これに伴い、 CoP が即座に前方に変位し、CoG に対してオーバーシュートする。 これによって身体を後方に起こす反力を発生させて姿勢を修正する。 すなわち人間は、床面振動の外乱を受けて $\mathrm{CoM}$ および $\mathrm{CoG}$ が動摇 した場合、 $\mathrm{CoP}$ の位置を制御することで立位姿勢を保持している。

これらの考察に基づき、次章では、 $\mathrm{CoP}, \mathrm{CoM}$ および $\mathrm{CoG}$ の挙動 を再現可能な台車型倒立振子モデルに基づく人体の地震応答解析モ デルを構築する。

\section{3. 人体の地震応答解析モデル}

\section{1 モデルの概要}

前章において、加振中の被験者の頭部・肩・腰は同位相で振動し ていることが示された。これを考慮し、踝より上部の下腿および大 腿、体幹部、両腕、頭部を一本の剛体棒 (単振子) でモデル化した 台車型倒立振子（Cart-type single-link inverted pendulum）によ り人間の地震応答解析モデルを構築する。解析モデルを Fig. 8 に示 す。台車に乗った倒立振子でモデル化することで、立位姿勢制御に おけるステップ方略による足の踏み出しを含めた CoP の挙動を表 現することが出来る。

本解析モデルの水平方向の力のつり合いおよび振子下端点回りの モーメントのつり合いから、次式が得られる。

$$
\begin{aligned}
& \left(m_{c}+m_{p}\right)\left\{\ddot{\xi}(t)+\ddot{\xi}_{0}(t)\right\}+m_{p} l_{p} \cos \theta(t) \cdot \ddot{\theta}(t)= \\
& -\mu_{c} \dot{z}(t)+m_{p} l_{p} \dot{\theta}(t)^{2} \sin \theta(t)+f_{c}(t) \\
& m_{p} l_{p} \cos \theta(t)\left\{\ddot{\xi}(t)+\ddot{\xi}_{0}(t)\right\}+\left(J_{p}+m_{p} l_{p}^{2}\right) \ddot{\theta}(t)= \\
& -\mu_{p} \dot{\theta}(t)+m_{p} g l_{p} \sin \theta(t)
\end{aligned}
$$

ここに、 $m_{p}$ および $m_{c}$ は振子および台車の質量、 $l_{p}$ は振子の質量中心 $(\mathrm{CoM})$ 高さ、 $J_{p}$ は振子の慣性モーメント、 $\mu_{p}$ および $\mu_{c}$ は振子および 台車の粘性減衰係数、 $g$ は重力加速度である。また、 $\theta(t)$ は振子の角 度、 $\xi(t)$ は台車の床に対する相対変位、 $\xi_{0}(t)$ は床の絶対変位、 $f_{c}(t)$ は台
車に加える駆動力である。前章で述べた $\mathrm{CoP}$ は、振子の下端の床面 投影点に対応し、 $\mathrm{CoG}$ は振子の質量中心 $(\mathrm{CoM})$ の床面投影点に対 応する。本解析モデルの $\theta(t)$ は、鉛直線と振子のな寸角に対応する (以降、重心角度 (Angle of CoM))。

式(7)および式(8)において、 $\theta(t)$ が十分小さいと仮定し、 $\dot{\theta}^{2}(t) \simeq 0$, $\sin \theta(t) \simeq \theta(t), \cos \theta(t) \simeq 1$ として線形化すると、連続時間系における 線形時不変(Linear Time Invariant, LTI)システムの状態方程式は次式 で表される。

$$
\dot{\mathbf{x}}(t)=\mathbf{A x}(t)+\mathbf{B u}(t)
$$

$$
\mathbf{A}=\left[\begin{array}{cccc}
0 & 0 & 1 & 0 \\
0 & 0 & 0 & 1 \\
0 & -\frac{m_{p}^{2} l_{p}^{2} g}{N} & -\left(J_{p}+m_{p} l_{p}^{2}\right) \frac{\mu_{c}}{N} & \frac{m_{p} l_{p}}{N} \mu_{p} \\
0 & \frac{m_{c}+m_{p}}{N} m_{p} l_{p} g & \frac{m_{p} l_{p}}{N} \mu_{c} & -\frac{m_{c}+m_{p}}{N} \mu_{p}
\end{array}\right]
$$

$$
\mathbf{B}=\left[\begin{array}{cc}
0 & 0 \\
0 & 0 \\
-1 & \frac{\left(J_{p}+m_{p} l_{p}^{2}\right)}{N} \\
0 & -\frac{m_{p} l_{p}}{N}
\end{array}\right]
$$

$$
N=\left(m_{c}+m_{p}\right) J_{p}+m_{c} m_{p} l_{p}^{2}
$$

$$
\mathbf{u}(t)=\left[\begin{array}{ll}
\ddot{\xi}_{0}(t) & f_{c}(t)
\end{array}\right]^{T}
$$

$$
\mathbf{x}(t)=\left[\begin{array}{llll}
\xi(t) & \theta(t) & \dot{\xi}(t) & \dot{\theta}(t)
\end{array}\right]^{T}
$$

ここに、 $\mathbf{u}(t)$ は倒立振子モデルへの入力ベクトル、 $\mathbf{x}(t)$ は状態ベクト ルである。

本解析モデルのブロック線図を Fig. 9 に示す。本研究では、人間 が床面の加速度外乱を受ける際、床面に対して垂直の姿勢を保持し て静止するよう姿勢制御を行うと考える。すなわち、本研究では制 御システムとして状態フィードバックを採用し、式(14) に示した状 態（床面に対する重心の相対变位、相対速度、角度、角速度）を全 てゼロにするよう制御を行う（Fig. 9 中の目標值 $\mathbf{r}$ が全てゼロ）と する。この場合、倒立振子（Fig. 9 中の P) の出力方程式は次式で 
表される。

$$
\begin{aligned}
& \mathbf{y}(t)=\mathbf{C x}(t) \\
& \mathbf{C}=\left[\begin{array}{llll}
1 & & & \\
& 1 & & \\
& & 1 & \\
& & & 1
\end{array}\right]
\end{aligned}
$$

ここに、 $\mathbf{y}(t)$ は時刻 $t$ における倒立振子の出力である。このとき、式 (7)および式(13)の台車への駆動力 $f_{c}(t)$ は、次式で表される。

$$
f_{c}(t)=-\mathbf{K x}(t)
$$

また、Kは次式で表されるフィードバックゲインである。

$$
\mathbf{K}=\left[\begin{array}{llll}
k_{\xi} & k_{\theta} & k_{\dot{\xi}} & k_{\dot{\theta}}
\end{array}\right]
$$

ここに、 $k_{\xi}, k_{\theta}, k_{\dot{\xi}} お よ ひ ゙ k_{\dot{\theta}}$ はそれぞれ台車の振動台に対する相対 変位、重心角度、台車の相対速度および振子の角速度に対するフィ ードバックゲインである。

人間の立位姿勢制御では、神経系により逐次制御されるため、神 経伝達時間や脳内での情報処理時間、神経一筋一骨格系における制 御力生成時間等に起因する時間遅れが存在することが知られている 17), 42)。本研究では、この時間遅れをフィードバック制御系における むだ時間(Time delay)として考慮し、状態と目標值との差を一定時 間遅延させてから制御器に入力する。これと式(9)〜 (18)より、床面 加速度蒙から出力 $\mathbf{y}$ までの伝達関数 $\mathbf{G}_{\mathbf{y} \ddot{\xi}_{0}}(\mathrm{~s})$ は次式で表される。

$\mathbf{G}_{\mathbf{y} \xi_{a}}(s)=\left\{\mathbf{I}+\mathbf{C}(s \mathbf{I}-\mathbf{A})^{-1} \mathbf{B}\left[\begin{array}{c}0 \\ \mathbf{K} e^{-\tau s}\end{array}\right]\right\}^{-1} \mathbf{C}(s \mathbf{I}-\mathbf{A})^{-1} \mathbf{B}\left[\begin{array}{l}1 \\ 0\end{array}\right]$

ここに、 $s$ はラプラス演算子、 $\tau$ はむだ時間である。

\section{2 フィードバックゲインの設定}

振動台搭乗実験における Case 3 の実験データに基づきフィード バックゲインを調整する。倒立振子のパラメータの設定值を Table 3 に示す。振子の長さと質量は被験者の身長と体重を用いた。慣性 モーメントは、文献 19)に基づき人体各部位の重心高さおよび質量 分布から算出した。また、文献 17 )を参照し、むだ時間 $\tau$ を $0.1 \mathrm{~s}$ と した。

振動台搭乗実験の Case 3 の Y 方向における CoP 相対変位および 重心角度の振動台加速度に対する周波数応答関数を Fig. 10 に示す。 人体は非線形システムであると考えられるが、本研究では前節で示 した等価線形モデルで人体の地震時挙動を近似可能であると考え、 実験と解析モデルの周波数応答関数を比較する。振動台搭乗実験に おける周波数応答関数と式(19)から求められる周波数応答関数が対 応寸るように、フィードバックゲインを Table 4 に示す通りに設定 した。設定したフィードバックゲインを用いて求めた周波数応答関 数を Fig. 10 に併記した。実験における位相はばらつきが大きく、 式(19)から求められる周波数応答関数の位相との対応関係は明瞭で はないものの、 $\mathrm{CoP} の 1 \mathrm{~Hz}$ 以下の周波数帯においては、実験と解 析モデルで良好に対応している。振幅については、高い振動数帯で 実験と解析モデルが対応していない部分があるものの、低周波数帯 においては実験と解析モデルの振幅は良好に対応している。

Case 3 の実験における振動台加速度を入力として解析を行った。 実験と解析による $\mathrm{CoP}$ および CoG の振動台に対する相対変位、重

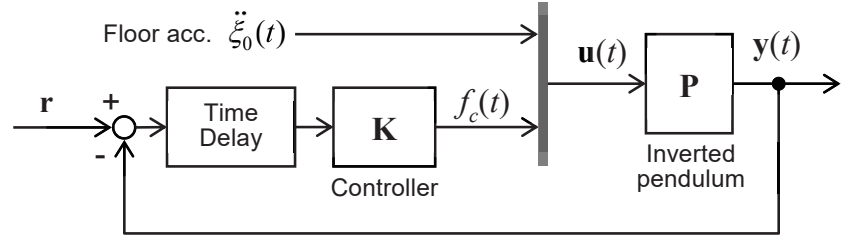

Fig. 9 Block diagram

Table 3 Parameter

\begin{tabular}{cccccccc}
\hline$m_{\mathrm{p}}$ & $m_{\mathrm{c}}$ & $l_{\mathrm{p}}$ & $g$ & $J_{\mathrm{p}}$ & $\mu_{\mathrm{p}}$ & $\mu_{\mathrm{c}}$ & $\tau$ \\
\hline $57 \mathrm{~kg}$ & $0.1 \mathrm{~kg}$ & $0.85 \mathrm{~m}$ & $9.8 \mathrm{~m} / \mathrm{s}^{2}$ & $92.0 \mathrm{kgm}^{2}$ & $0 \mathrm{Ns} / \mathrm{m}$ & $10000 \mathrm{Ns} / \mathrm{m}$ & $0.1 \mathrm{~s}$ \\
\hline
\end{tabular}
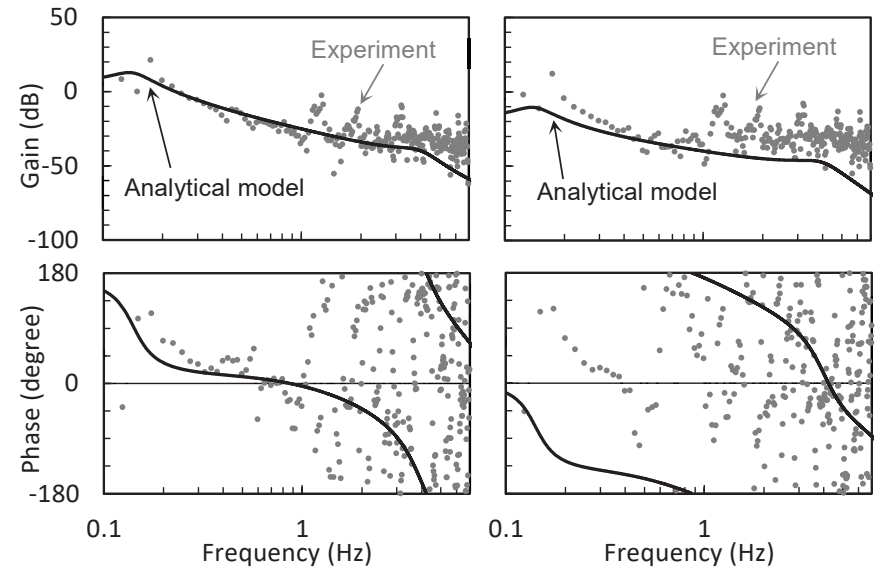

a) Relative disp. of CoP / input acc. b) Angle of CoM / input acc. Fig. 10 Frequency response function (Case 3 )

Table 4 Feedback gain

\begin{tabular}{rcrc}
\hline$k_{\xi}(\mathrm{N} / \mathrm{m})$ & $k_{\theta}(\mathrm{Nm} / \mathrm{rad})$ & $k_{\dot{\xi}}(\mathrm{Ns} / \mathrm{m})$ & $k_{\dot{\theta}}(\mathrm{Nms} / \mathrm{rad})$ \\
\hline-15400 & -262000 & -20400 & -70700 \\
\hline
\end{tabular}

心角度および CoG と頭部の振動台に対する相対速度の時刻歴波形 を Fig. 11 a）に示す。解析モデルにおける頭部の相対速度は、振子 の上端部分に対応し、重心の角速度 $\dot{\theta}(t)$ に振子の全長 $\left(2 I_{p}\right)$ を乗じ て求めた。解析における重心角度の振幅や位相が実験結果と異なる ものの、解析における $\mathrm{CoP}$ および CoG の相対変位や、CoG および 頭部の相対速度は、振幅、位相とも実験結果と良好に対応している。

\section{3 解析モデルの妥当性の検証}

次に、構築された解析モデルに対し、振動台搭乗実験における Case 6 の振動台加速度を入力し、モデルの応答と実験における被験 者の応答を比較することで、解析モデルの妥当性を検証する。

Case 6 における実験と解析の $\mathrm{CoP}$ 相対変位、 $\mathrm{CoG}$ 相対変位、重 心角度および CoG と頭部の振動台に対する相対速度の時刻歴波形 を Fig. 11 b）に示す。解析の重心角度の振幅は実験に比べ若干小さ く、位相も異なるものの、解析における $\mathrm{CoP}$ および CoG の相対変 位や、CoG および頭部の相対速度は、振幅・位相とも実験結果と良 好に対応している。

解析モデルの妥当性をさらに検討するため、Case 1〜 7 の全加振 ケースにおける振動台加速度を解析モデルに入力し、算出された $\mathrm{CoP}$ や CoG、頭部の挙動を実験結果と比較する。

$\mathrm{CoP}$ および CoG の振動台に対する相対変位の最大值の実験結果 

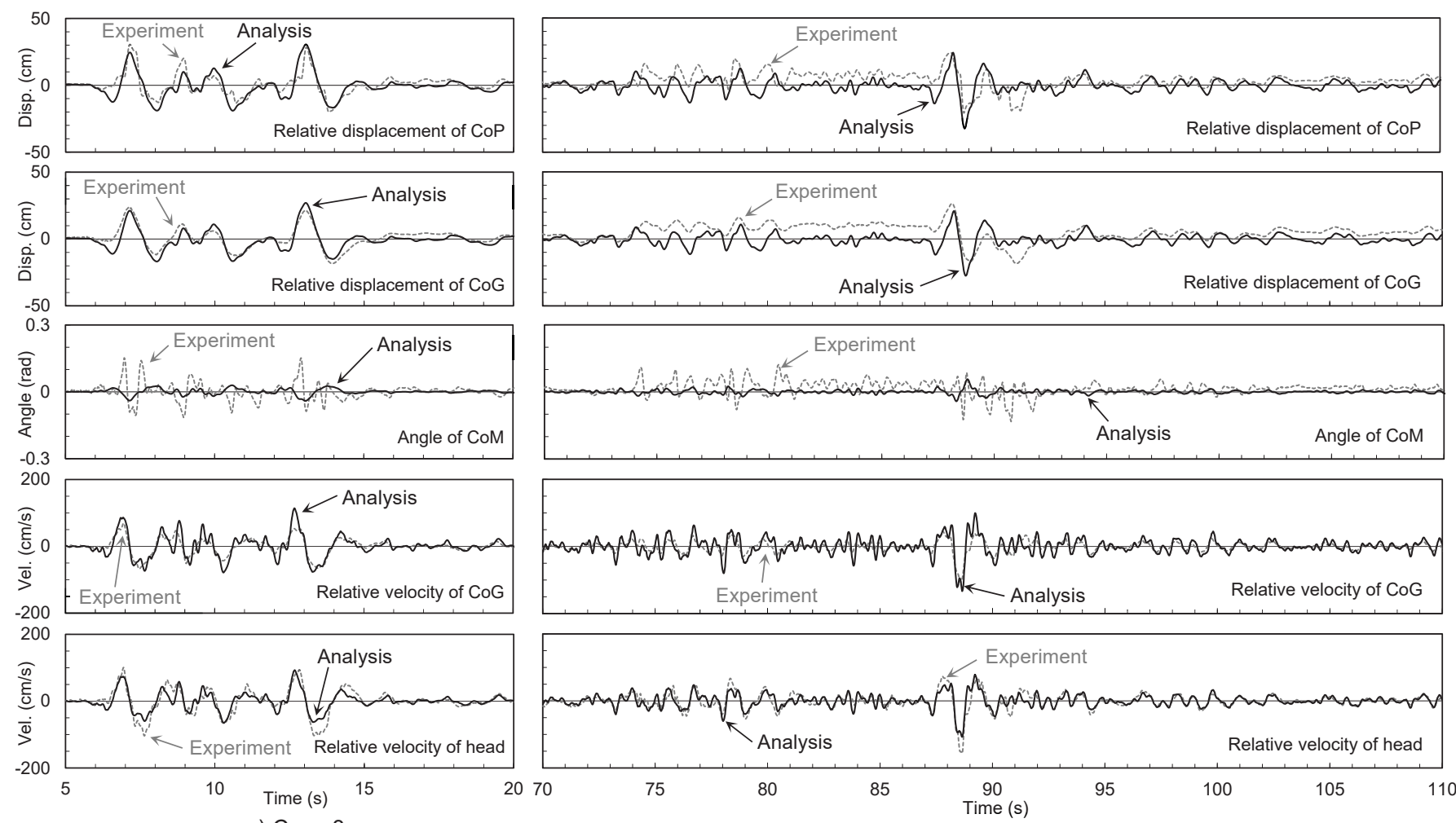

a) Case 3

b) Case 6

Fig. 11 Time histories of CoP, CoG, Angle of CoM and head

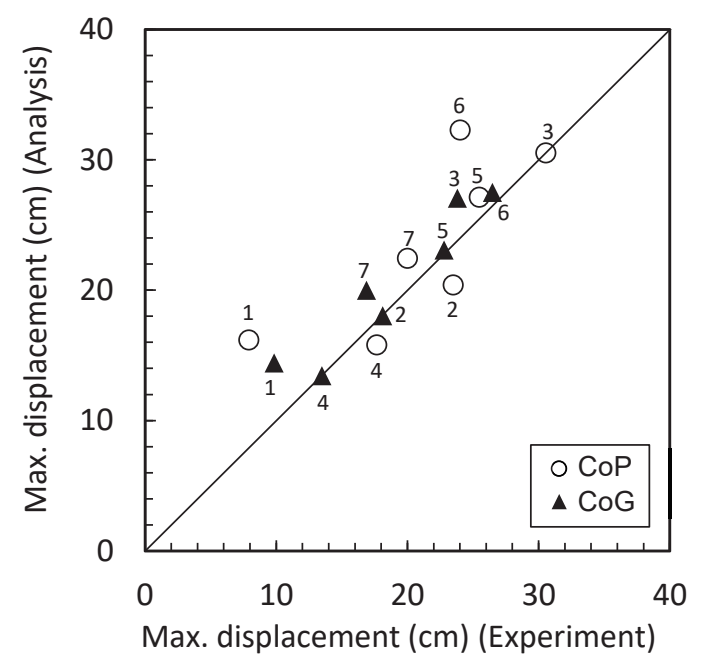

Fig. 12 Relationship between maximum displacements of experiments and those of analyses (Number: Case No. of experiment)

と解析結果の関係を Fig. 12 に示す。同図中の数字は、加振ケース 番号を示している。CoP、CoG とも、解析における最大相対変位は 実験結果と良好に対応している。

Case 1〜 7 における頭部および CoG の振動台に対する相対速度 の最大值の実験結果と解析結果の関係を Fig. 13 に示寸。CoG の速 度の解析結果は、実験結果に比べて若干過大評価となっている。一 方、頭部速度の解析結果は、速度が小さい範囲では実験結果と良好 に対応するものの、速度が大きい範囲で実験に比べて若干過小評価 となっている。これらの差異の要因としては、本研究では人体を単 振子によりモデル化しており、被験者の上半身の挙動が十分に再現

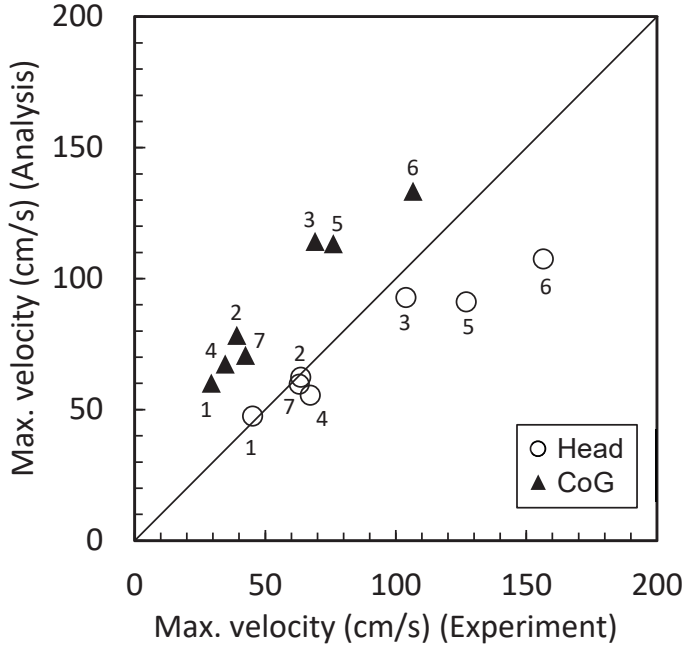

Fig. 13 Relationship between maximum velocities of experiments and those of analyses (Number: Case No. of experiment)

されていないこと等が考えられる。ただし、Fig. 13 において、GoG と頭部とも、実験ケース間の大小関係は良好に再現されている。

以上のことから、本研究において構築した人体の地震応答解析モ デルを用いて、人間の前後方向の地震時挙動を良好な精度で再現で きることが示された。本研究では踝より上部の身体を単振子とした 台車型倒立振子で人体をモデル化したが、多重倒立振子等へのモデ ルの改良等による解析精度のさらなる向上は、今後の課題である。

\section{4. 結論}

本研究では、地震時における人的被害の予測に向けて、振動台搭 
乗実験に基づき、人体の地震応答解析モデルを構築した。得られた 知見を以下に示す。

1）振動台搭乗実験の被験者の頭部、肩および腰の挙動は同位相で あった。地震時において、人間は主に足関節方略とステップ方 略により立位姿勢制御を行い、股関節方略は卓越しない。

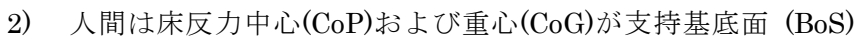
内に収まるように姿勢制御を行っている。 CoG が BoS を逸脱 する (もしくは逸脱しそうになる) と、ステップ方略により BoS を広げることで姿勢制御を行う。

3）踝より上部を単振子とした台車型倒立振子モデルにより、人体 の前後方向（矢状面方向）の地震応答解析モデルを構築した。 状態（CoP の床に対する相対変位と相対速度および $\mathrm{CoM}$ の角 度と角速度) フィードバック制御器を用いることで、地震時に おける人体の $\mathrm{CoP}$ と $\mathrm{CoG}$ の変位を良好に再現できた。

4） $\mathrm{CoP}$ および CoG の振動台に対する最大相対変位は良好に再現 できた。一方、CoG の最大相対速度は実験結果に比べて若干過 大評価となり、頭部の最大相対速度は実験結果に比べて若干過 小評価となった。

多重倒立振子等によるモデルの精緻化や、他の制御方法の利用等 による解析モデルの精度のさらなる向上は、今後の課題である。

\section{謝辞}

本研究は、文部科学省の平成 27 年度英知を結集した原子力化学 技術・人材育成推進事業 No.27110 (代表：高田毅士) および平成 28 年度科学研究費補助金若手研究(B) No.16K21011（代表：肥田剛典） の助成により遂行しました。原子力発電所内の観測記録は東京電力 (株)から提供されたものを使用しました。振動台搭乗実験に際して は、東京大学腰原研究室の大塚日出夫氏ならびに東京大学高田研究 室の学生諸氏に多大なご協力をいただきました。関係各位に謝意を 表します。

\section{参考文献}

1) National Research Institute of Fire and Disaster: Survey Report on Damages and Fire-fighting Activities of the 2004 Niigata Prefecture Chuetsu Earthquake, Research materials of NRIFD, No. 69, 2005. 9 (in Japanese) 独立行政法人消防研究所：平成 16 年(2004 年)新潟県中越地震被害およ び消防活動に関する調查報告書，消防研究所研究資料第 69 号, 2005. 9

2) Shizuoka Prefecture: Summary of Earthquake Damage and Disaster Prevention Activities with Suruga Bay Earthquake at August 11, 2009, http://www.pref.shizuoka.jp/bousai/e-quakes/shiraberu/higai/surugaw anjishin/index.html, 2011.3 (accessed 2018. 5. 15) (in Japanese) 静岡県: 平成 21 年 8 月 11 日の駿河湾を震源とする地震被害および防災 対応 $の$ 概要, http://www.pref.shizuoka.jp/bousai/e-quakes/shiraberu/ higai/surugawanjishin/index.html, 2011.3 (2018. 5. 15 閲覧)

3) Fire and Disaster Management Agency: About the 2011 off the Pacific Coast of Tohoku Earthquake, http://www.soumu.go.jp/main_content 1000109170. pdf (accessed 2018. 4. 12) (in Japanese) 消防庁災害対策本部：平成 23 年(2011 年)東北地方太平洋沖地震(東日本 大震災)について, http://www.soumu.go.jp/main_content/000109170. pdf (2018. 4. 12 閲覧)

4) Kumamoto Prefecture: Disaster Countermeasure Headquarters Conference on the 2016 Kumamoto Earthquake, http://www. pref.ku mamoto.jp/kiji_15459.html (accessed 2018. 4. 12) (in Japanese) 熊本県: 平成 28 年熊本地震に関する災害対策本部会議資料, http://www. pref.kumamoto.jp/kiji_15459.html (2018.4. 12 閲覧)
5) Motoyuki Ushiyama, Saki Yokomaku and Koichi Sugimura: Characteristics of victims of the 2016 Kumamoto Earthquake, J. JSNDS, Japan Society for Natural Disaster Science, Vol. 35, No. 3, pp. 203-215, 2016 (in Japanese)

牛山素行, 横幕早季, 杉村晃一: 平成 28 年熊本地震による人的被害の特 徵, 自然災害科学, 日本自然災害学会, Vol. 35, No. 3, pp. 203-215, 2016

6) Eisuke Ikuta, Michio Miyano, Eiichi Itoigawa, Akiyoshi Nishimura, Hiroshi Tanaka, Kouichi Kajiwara and Yoshio Kumagai: Analysis on the Mechanism of Human Casualties due to the 1995 HyogokenNanbu Earthquake Based on the Comprehensive Database, Journal of Architecture and Planning (Transactions of AIJ), No. 590, pp. 117-123, 2005. 4 (in Japanese)

生田英輔, 宮野道雄, 系魚川栄一, 西村明儒, 田中裕, 梶原浩一, 熊谷良 雄：統合データベースに基づく兵庫県南部地震による人的被害の発生機 構に関する分析, 日本建築学会計画系論文集, 第 590 号, pp. 117-123, 2005. 4

7) Mika Kaneko: Method to Estimate Overturning Ratios of Furniture During Earthquake, Journal of Structural and Construction Engineering (Transactions of AIJ), No. 551, pp. 61-68, 2002. 1 (in Japanese)

金子美香：地震時における家具の転倒率推定法，日本建築学会構造系論 文集，第 551 号, pp. 61-68, 2002. 1

8) Toshiyuki Masatsuki and Saburoh Midorikawa: Simulation of Seismic Behavior of Furniture in High-rise Residential Buildings due to Longperiod Ground Motion, Journal of JAEE, Japan Association for Earthquake Engineering, Vol. 15, No. 6, pp. 1-11, 2015. 11 (in Japanese)

正月俊行，翠川三郎：長周期地震動による超高層集合住宅での家具群の 地震時挙動シミュレーション, 日本地震工学会論文集, 第 15 巻, 第 6 号, pp. 1-11, 2015. 11

9) Hiroaki Ogino, Takuzo Yamashita, Mika Kaneko, and Daigoro Isobe: Development of a Finite Element Code to Simulate Behaviors of Furniture under Seismic Excitation, Journal of Structural and Construction Engineering (Transactions of AIJ), Vol. 80, No. 717, pp. 1687-1697, 2015. 11 (in Japanese)

荻野弘明，山下拓三，金子美香，磯部大吾郎：家具・什器の地震時挙動を 再現する有限要素解析手法の開発, 日本建築学会構造系論文集, 第 80 巻, 第 717 号, pp. 1687-1697, 2015. 11

10) Michio MIYANO, Eisuke IKUTA, Fumio NAGASHIMA, Hiroshi TANAKA, Kouichi KAJIWARA and Michiko OKUNO: Study on Measurement Way of the Human Body Damage Caused by Earthquake -Dummy Development for Thoracic Compression Experiment-, Journal of Social Safety Science, No. 10, pp. 49-54, 2008. 11 (in Japanese)

宮野道雄, 生田英輔, 長嶋文雄, 田中裕, 梶原浩一, 奥野倫子：地震時の 人体被災度計測手法の開発一胸部圧迫実験用ダミーの作成一, 地域安 全学会論文集, No. 10, pp. 49-54, 2008. 11

11) Toru TAKAHASHI, Shinya WATANABE, Yukiko NAKAMURA, and Taiki SAITO: Study on the impact of furniture turnover onto human during strong motion -Experimental study of furniture turnover using dummy doll-, Journal of JAEE, Japan Association for Earthquake Engineering, Vol. 16, No. 3, pp. 126-136, 2016. 3 (in Japanese) 高橋徹，渡辺慎也，中村友紀子，斉藤大樹：強震時の家具の転倒が人体に 及ぼす影響に関する研究 ーダミー人形を用いた家具の転倒実験-, 日本地 震工学会論文集, 第 16 巻, 第 3 号（特集号）, pp. 126-136, 2016. 3

12) Yoshiro Kai and Kouichi Kajiwara: Study on dynamic response characteristics of human body under the seismic motion using shaking table test of crash test dummies, AIJ Journal of Technology and Design, Vol. 17, No. 36, pp. 767-772, Jun., 2011.6 (in Japanese) 甲斐芳郎，梶原浩一：人体ダミーの加振実験による地震時人体応答特性, 日本建築学会技術報告集, 第 17 巻, 第 36 号, pp. 767-772, 2011.6

13) Hakusan Corporation: Earthquake Simulator "Jishin the Vuton", http://www.hakusan.co.jp/products/eq_simulator/, (accessed 2018. 5. 16) (in Japanese)

白山工業：可搬型地震動シミュレーター 地震ザブトン, http://www. hakusan.co.jp/products/eq_simulator/, (2018.5. 16 閲覧) 
14) Takenori Hida, Seiyo Warita, Tatsuya Itoi and Tsuyoshi Takada: Investigation on psychological condition and time-variant vibration characteristics of human during earthquake based on earthquake simulator test, Proceedings of the 12th Annual Meeting of Japan Association for Earthquake Engineering, JAEE, P1-41, 2016. 9 (in Japanese)

肥田剛典, 割田聖洋, 系井達哉, 高田毅士：地震体験実験に基づく人間の 摇れの体感と時変振動特性に関する研究, 日本地震工学会第 12 回年次大 会梗概集, 日本地震工学会, P1-41,2016.9

15) Takahashi, T., Suzuki, T., Saito, T., Azuhata, T. and Morita, K.: Shaking Table Test for Indoor Human Response and Evacuation Limit, Journal of 5th International Conference on Earthquake Engineering, pp. 187-193, 2010. 3

16) Aino Sakamoto, Kento Suzuki, Tomonobu Kaneko, Takehiko Tanuma, Takenori Hida, and Masayuki Nagano: Study on physical condition of residents in super high-rise residential buildings during earthquake based on shaking table boarding tests -Part4 Effects of posture on perception and human head response-, Summaries of Technical Papers of Annual Meeting, Architectural Institute of Japan, Structures-II, pp. 41-42, 2016. 8 (in Japanese) 坂本あいの, 鈴木賢人, 金子知宣, 田沼毅彦, 小田聡, 肥田剛典, 永野正 行：振動台搭乗実験に基づく超高層集合住宅居住者の地震時の体感に関 する検討 一その 4 姿勢の違いによる体感と人間頭部の応答の比較一, 日本建築学会大会学術講演梗概集, 構造-II, pp. 41-42, 2016.8

17) R. J. Peterka: Sensorimotor Integration in Human Postural Control, J. Neurophysiol, Vol. 88, American Physiological Society, pp. 1097-1118, 2002.09

18) Herman van der Kooij, Edwin van Asseldonk, and Frans C. T. van der Helm: Comparison of different methods to identify and quantify balance control, Journal of Neuroscience Methods, 145, pp. 175-203, 2005

19) Masashi YAMAMOTO: Human body dynamics under horizontal ground motions: Shaking-table tests and simplified modeling under standing conditions, Journal of Structural and Construction Engineering (Transactions of AIJ), Vol. 76, No. 667, pp. 1631-1637, 2011. 9 (in Japanese)

山本雅史：水平地動を受ける人体の動特性：振動台実験および立位時簡 易人体モデル, 日本建築学会構造系論文集, 第 76 巻, 第 667 号, pp. 1631-1637, 2011. 9

20) Masashi YAMAMOTO, Hiroki HAMAGUCHI and Masahiko HIGASHINO: A proposal of an index to evaluate human sense utilizing an analytical model of human body dynamics, Summaries of Technical Papers of Annual Meeting, Architectural Institute of Japan, Environmental Engineering-I, pp. 359-360, 2012. 9 (in Japanese) 山本雅史, 濱口弘樹, 東野雅彦: 人体の振動解析モデルを用いた体感評 価尺度の提案, 日本建築学会大会学術講演梗概集, 環境工学- I, pp. 359$360,2012.9$

21) Versace, J.: A review of the severity index, Proc. of 15th Stapp Car Crash Conference, pp. 771-796, 1971.

22) NHTSA: Development of improved injury criteria for the assessment of advanced restraint systems-II, 1999.

23) Atsushi Ohno, Seiyo Warita, Takenori Hida, Tatsuya Itoi, and Tsuyoshi Takada: Basic analysis for seismic response analysis model of human based on shaking table test -investigation ZMP and postural stabilization strategy-, Summaries of Technical Papers of Annual Meeting, Architectural Institute of Japan, Structures-II, pp. 409-410, 2017. 7 (in Japanese)

大野敦史, 割田聖洋, 肥田剛典, 系井達哉, 高田毅士：振動台搭乗実験に 基づく人体の地震応答解析モデル構築に向けた基礎的検討 -ZMP と姿勢 保持方略の関係の分析-, 日本建築学会大会学術講演梗概集, 構造-II, pp. 409-410, 2017. 7

24) Takenori Hida, Seiyo Warita, Tatsuya Itoi, and Tsuyoshi Takada: Development of Seismic Countermeasures Against Cliff Edges for Enhancement of Comprehensive Safety of Nuclear Power Plants -Part 5: Experimental analysis of human body against seismic motions-, Transactions of the 24th SMiRT, Busan, Korea, D7-S2, 2017. 8
25) Takenori Hida, Seiyo Warita, Tatsuya Itoi, and Tsuyoshi Takada: Study on Seismic Safety Assessment of Human Based on Shaking Table Tests, PSAM Topical Conference on Human Reliability, Quantitative Human Factors, and Risk Management, Munich, Germany, 2017.6

26) Winter, D. A.: Biomechanics and Motor Control of Human Movement, 4th Edition, 2009. 10

27) Japan Association for Earthquake Engineering: Strong Motion Data at Kashiwazaki-Kariwa Nuclear Power Plant, TEPCO, DVD, Revised edition. 2010. 6 (in Japanese)

日本地震工学会：東京電力(株) 柏崎刈羽原子力発電所における強震デー 夕全記録 (DVD) ＜改訂版>2010.6

28) Japan Association for Earthquake Engineering: Strong Motion records observed at Fukushima Daiichi Nuclear Power Plant and Fukushima Daini Nuclear Power Plant during the 2011 off the Pacific coast of Tohoku Earthquake, DVD, Revised edition, 2011. 5 (in Japanese) 日本地震工学会: 東京電力(株) 平成 23 年 3 月 11 日に発生した東北地方 太平洋沖地震においての福島第一原子力発電所および福島第二原子力発 電所で観測された強震観測記録等の強震データ記録 $($ DVD) <改訂版 > , 2011. 5

29) Open Source Computer Vision Library, https://opencv.org/ (accessed 2018. 4. 11)

30) DITECT Co. Ltd.: DIPP-Motion V/3D, https://www.ditect.co.jp/en/ (accessed 2018. 4.12)

31) D. Gordon E. Robertson, Graham E. Caldwell, Joseph Hamill, Gary Kamen, and Saunders N. Whittlesey: Research Methods in Biomechanics Second edition, Human Kinetics, 2013

32) C. E. Clauser, J. T. McConville and J. W. Young: Weight, volume and center of mass of segments of the human body, Aerospace Medical Research Laboratory technical report, TR-69-70, 1969. 8

33) R. F. Chandler, C. E. Clauser, J. T. McConville, H. M. Reynolds, and J. W. Young: Investigation of Internal Properties of the Human Body, Aerospace Medical Research Laboratory technical report, TR-74-137, 1975. 3

34) Horak FB and Macpherson JM: Postural orientation and equilibrium. In: Rowell LB and Shepherd JT (Eds) Handbook of Physiology: Section 12: Exercise: Regulation and Integration of Multiple Systems. An American Physiological Society Book, pp. 255-292, 1996

35) Shumway-Cook A and Woollacott MH: Mortor Control: theory and practical application. $2^{\text {nd }}$ ed., Lippincott Williams \& Wilkins (Maryland), pp. 163-191, 2000

36) Horak, F. B., and L. M. Nashner: Central programming of postural movements: adaptation to altered support-surface configurations. J. Neurophysiol. 55: pp. 1369-1381, 1986

37) Nashner, L. M.: Fixed patterns of rapid postural responses among leg muscles during stance. Exp. Brain Res. 30: pp. 13-24, 1977

38) Nashner, L. M., and G. McCollum: The organization of human postural movements: a formal baias and experimental synthesis. Behav. Brain Sci. 8: pp. 135-172, 1985

39) McIlroy, W. E., and B. E. Maki: Changes in early 'automatic' postural responses associated with the prior-planning and execution of a compensatory step. Brain Res. 631: pp. 203-211, 1993

40) Winter, D. A., A. E. Patla, F. Prince, M. G. Ishac, and K. Gielo-Perczak: Stiffness Control of Balance in Quiet Standing, J. Neurophysiol. 80(3), pp. 1211-1221, 1998. 9

41) Horak F and Kuo A: Postural adaptation for altered environments, tasks, and intentions, Jack M. Winters and Patrick E. Crago (Eds): Biomechanics and Neural Control of Posture and Movement, SpringerVerlag, pp. 267-281, 2000

42) Kei Masani, Albert H. Vette and Milos R. Popovic: Controlling balance during quiet standing: Proportional and derivative controller generates preceding motor command to body sway position observed in experiments, Gait Posture, 23, pp. 164-172, 2006 


\section{CONSTRUCTION OF SEISMIC RESPONSE ANALYTICAL MODEL OF HUMAN BODY FOR PREDICTING HUMAN DAMAGE DURING EARTHQUAKE}

Simulation analysis based on shaking table test and cart-type inverted pendulum model

$$
\begin{gathered}
\text { Takenori HIDA }{ }^{* 1}, \text { Atsushi OHNO }{ }^{* 2}, \text { Tatsuya ITOI }{ }^{* 3} \\
\text { and Tsuyoshi TAKADA }
\end{gathered}
$$

\footnotetext{
${ }^{* 1}$ Assist. Prof., Dept. of Architecture, Graduate School of Engineering, The University of Tokyo, Dr.Eng.

${ }^{* 2}$ Grad. Student, Dept. of Architecture, Graduate School of Engineering, The University of Tokyo

${ }^{* 3}$ Assoc. Prof., Resilience Engineering Research Center, Graduate School of Engineering, The University of Tokyo, Dr.Eng:

${ }^{*}$ Prof., Dept. of Architecture, Graduate School of Engineering, The University of Tokyo, Dr.Eng.
}

So many human damages have been reported during past earthquake. Some of them got injured due to falling and crashing to furniture. Critical structures such as chemical plants and nuclear power plants, it is required to take countermeasures after accidents to prevent harmful substance leakage in the event of a severe accident caused by an earthquake. However, if the workers are injured during earthquake, the retrieval activities might become difficult for the workers. In addition, in order to predict the indoor human damage due to huge earthquake such as the Nankai Trough earthquake, it is important to grasp the behavior of human during an earthquake. To predict injuries resulting from human falling and crashing to furniture due to earthquake shaking, it is necessary to evaluate the seismic response of the human body.

From the view point of the above background, in order to construct a seismic response analytical model of a human body, we conducted shaking table tests with human subject. The seismic response characteristics of the human body during shaking were investigated. The behavior of human subject during excitation was observed by 3-D motion capture system. The center of pressure $(\mathrm{CoP})$ on the floor of the human subject was measured by a force plate during the excitation. Then, the mechanisms of postural control of the human subject were investigated. The human subject controlled his posture by moving the CoP to place the center of gravity (CoG) within the base of support (BoS). When CoG deviates from BoS, the human subject controlled his posture by widening BoS through the stepping strategy.

Next, the seismic response analytical model in the forward-backward direction (sagittal plane direction) of a human was constructed based on the cart-type single-link inverted pendulum model with state feedback controller. The displacement of CoP, CoG, velocity of CoG and head could be evaluated by the model. The frequency response function of human subject during excitation in the experiment and that of the analytical model were compared in order to set the appropriate feedback gain of the controller. The displacement of $\mathrm{CoP}, \mathrm{CoG}$, velocity of CoG and head evaluated by the analytical model showed good agreement with those of the experimental results.

Finally, the validity of the model was verified by the simulation analysis with other input motion. The maximum displacement of $\mathrm{CoP}$ and $\mathrm{CoG}$ could be well reproduced. On the other hand, the velocity of CoG was slightly overestimated compared to the experimental result, and the velocity of the head was slightly underestimated compared with the experimental result. Improvement of accuracy of the seismic response model (e.g. modeling with double inverted pendulum or using other control methods, etc.) is a future task. 